\title{
Prevalence of diarrheal diseases and associated factors among under-five children in Dale District, Sidama zone, Southern Ethiopia: a cross-sectional study
}

Behailu Melese ${ }^{1}$, Wondimagegn Paulos ${ }^{2}$, Feleke Hailemichael Astawesegn ${ }^{3}$ and Temesgen Bati Gelgelu² ${ }^{*}$ (1)

\begin{abstract}
Background: Globally childhood diarrhoeal diseases continue to be the second leading cause of death, while in Ethiopia it kills half-million under-five children each year. Sanitation, unsafe water and personal hygiene are responsible for $90 \%$ of the occurrence. Thus, this study aimed to assess the prevalence and associated factors of diarrheal diseases among under-five children in Dale District, Sidama Zone, Southern Ethiopia.

Methods: A community-based cross-sectional study was conducted. A face to face interview using a structured questionnaire and observation checklist was used. A total of 546 households with at least one under-five children were selected using simple random sampling techniques. The data entry and cleaning were performed using Epidemiological information software (EPI Info) 3.5.1 and then exported to Statistical Package for Social Science (SPSS) version 16.0 for analysis. Frequencies and proportions were computed as descriptive analysis. Initially using bivariate analysis a crude association between the independent and dependent variables was investigated. Then, those variables with $p$-value $\leq 0.25$ were included in multivariable analysis to determine the predictor variables for the outcome variables. Finally, further analyses were carried out using multivariable analysis at a significance level of p-value $\leq 0.05$.
\end{abstract}

Results: A total of 537 children under the age of 5 years were included. The 2 weeks prevalence of diarrhea among children under the age of 5 years was 13.6, 95\% Cl (10.7, 16.5\%). Educational level [AOR: 3.97, 95\% Cl $(1.60,8.916)]$, age of indexed child [AOR: 12.18,95\% Cl $(1.78,83.30)]$, nutritional status [AOR: $6.41,95 \% \mathrm{Cl}(2.47,16.77)$.$] , hand$ washing method $[A O R, 3.10,95 \% \mathrm{Cl}(1.10,8.67)]$, hand washing after latrine $[A O R: 2.73,95 \% \mathrm{Cl}(1.05,6.56)]$, refuse disposal method [AOR, 3.23, 95\% Cl $(1.37,7.60)]$ and housing floor material [AOR: 3.22, 95\% Cl $(1.16,8.91$ ] were significantly associated with the occurrence of childhood diarrheal diseases.

Conclusion: Childhood diarrhea remains the commonest health problem in the study area. The findings have important policy implications for childhood diarrhoeal disease intervention programs. Thus, activities focusing on proper handwashing techniques at all appropriate times, proper refuse disposal, improving nutrition and better childcare also highly recommended.

Keywords: Dale District, Diarrhoeal diseases, Under-five children

\footnotetext{
*Correspondence: temesgenbati@gmail.com; batitemesgen@yahoo.com

${ }^{2}$ School of Public Health, College of Health Sciences and Medicine, Wolaita

Sodo University, Wolaita Sodo, Ethiopia

Full list of author information is available at the end of the article
}

(c) The Author(s). 2019 Open Access This article is distributed under the terms of the Creative Commons Attribution 4.0 International License (http://creativecommons.org/licenses/by/4.0/), which permits unrestricted use, distribution, and reproduction in any medium, provided you give appropriate credit to the original author(s) and the source, provide a link to the Creative Commons license, and indicate if changes were made. The Creative Commons Public Domain Dedication waiver (http://creativecommons.org/publicdomain/zero/1.0/) applies to the data made available in this article, unless otherwise stated. 


\section{Background}

According to world health organization (WHO), Diarrhea is characterized by three or more loose or liquid stools per day due to abnormally high fluid content of stool Or an abnormal increase in daily stool fluidity, frequency, and volume from what is considered normal for an individual [1]. Diarrheal diseases have been a major public health concern of low-income countries leading to high morbidity and mortality among under-five children [2].

Each year, an estimated 2.5 billion cases of diarrhea occur among children under the age of five, and estimates suggest that overall incidence has remained relatively stable over the past two decades [1]. Diarrheal diseases account for 1 in 9 or $9 \%$ of child deaths worldwide, making diarrhea the second leading cause of death among children under the age of five [3, 4] Globally, from all causes of child deaths that occurs daily,diarrheal diseases accounts 15\%/ more than 1600 children deaths under 5 years of age $[5,6]$.

In Africa and South Asia more than four-fifths of all under-five deaths (82\%) caused by diarrheal diseases [7]. From all deaths worldwide, about half of them due to pneumonia and diarrhea occur in just five most poor countries: namely India, Nigeria, the Democratic Republic of Congo, Pakistan, and Ethiopia [1]. Although Ethiopia has already achieved remarkable progress in reducing under-five mortality in the last decades, diarrheal diseases are still a common problem, Studies done in different parts of Ethiopia had shown that diarrhea is still a major public health problem. According to Ethiopia Demographic and Health Surveys (EDHS) of 2016, $12 \%$ of children under age five had diarrhea [8]. Similarly, this report showed that in southern nations nationalities and people region $13.9 \%$ of children under the age five have had diarrhea [8]. Particularly, in Sidama Zone Shebedino district the 2 weeks prevalence of diarrhea was (19.6\%) which is higher than that of regional and national prevalence [9].

Therefore, though the factors that contribute to the occurrence of diarrheal diseases among children under the age of 5 years is complex, the relative contribution of socioeconomic, environmental, and behavioral factors should not be underestimated [8]. Despite the emphasis given by the Ethiopian ministry of health and the respective regional health offices to improve child health still, many children are dying due to easily preventable and treatable diarrheal disease in Ethiopia. So, this study aimed to assess the prevalence and associated factors of diarrheal diseases among children under the age of 5 years. Knowing this information would help to design appropriate intervention strategies to avert diarrheal disease. It will also provide information for program providers and managers to address the gap. Furthermore, the findings obtained from this study will provide baseline information for further researchers.

\section{Methods \\ Study design and area}

A community-based cross-sectional study was conducted from October 1-25/2017 in Dale district, Southern Ethiopia. The District has 3 urban and 36 rural kebeles. Agriculture is the main livelihood of the population with Enset, Teff, maize, millet, barley, and legumes being the main crops cultivated in the district. The district has an estimated 272,212 total populations of these 42,492 are under-five children and 50, 113 households. In the district, there are one hospital, 10 health centers, 36 health posts \& three private health institutions that provide preventive and curative services to the community. The potential health services coverage of the Woreda was $70 \%$, but according to the annual report of Dale District health office, in 2015/16 Pneumonia, Helminthiasis, Diarrheal diseases, Acute Respiratory Infection and Malnutrition were the top five diseases of under-five morbidity in the district [10]. But there is no study documented on the prevalence and factors associated with diarrheal diseases in the district. Therefore, this study aimed to assess the prevalence and associated factors of diarrheal diseases among under-five children in Dale District, Sidama Zone, Southern Ethiopia.

\section{Study and source population}

Source population were all under-five children living in the Dale district and the study population were randomly selected households (HHs) with at least one under-five children.

\section{Sample size calculation}

The sample size was calculated using two population proportion formula with the following assumptions; 95\% level of confidence, $85 \%$ power of the test, design effect of 2 and $10 \%$ non-response rate. $\left(P_{1}=76.48 \%\right)$ the proportion of poor Waste Disposal among cases and $\left(P_{2}=\right.$ $59 \%)$ proportion of poor Waste Disposal among controls [11]. In the meantime, the sample size was calculated by the statical program of Epi Info 3.5.3. Then the final sample size was 546 .

\section{Sampling technique}

In the first stage, one urban kebele and ten rural kebeles were selected using simple random sampling from 3 urban and 36 rural Kebeles after stratifying the kebeles based on their residence. In the second stage after proportionally allocating a total sample size of $546 \mathrm{HHs}$ to each selected kebeles, then HHs with at least one underfive children were randomly selected. In the meantime, we used the lottery method to include one child for 
those HHs with more than one under-five children. The first household was selected randomly at the center of the kebele and the subsequent households were selected systematically to the left side of each household and sampling interval used for selected kebeles. When the selected households had no under-five children, the next neighborhood household was replaced.

\section{Data collection tools and methods}

The structured questionnaire was developed after reviewing relevant literature to include all the possible variables that address the objectives of the study. The questionnaire contains independent variables such as socioeconomic and demographic characteristics, demographic and health characteristics of the indexed children, behavioral factors and environmental sanitation factors. The questionnaire first prepared in English and then translated to local language Sidama and back-translated to English to maintain the consistency of the contents of the instrument using language expert. Face to face interviews was conducted by eight Diploma holders and supervised by two Degree holders to collect data about the above variables, besides this observational checklist was also used. Anthropometric indicators for children were collected based on a comparison of weight-for-age with a reference population of well-nourished children. Based on WHO Multicentre Growth Reference Study weight-for-age of the children was computed, then nutritional status determined. Consequently, those children whose weight-for-age found below minus two standard deviations (-2 SD) and minus three standard deviations (-3 SD) from the median of the reference population were categorized as moderately and severely malnourished respectively [12].

\section{Data quality assurance}

To assure the quality of data Diploma holder data collectors and Degree holder supervisors with health background were assigned. The training was provided for 2 days about interview technique, how to maintain quality of data, and ethical issue for data collectors and supervisors.

A pre-test was done on $5 \%$ of the sample size in three none selected kebeles of (2 rural and 1urban) the Dale District. Necessary corrections were made based on the finding of a pre-test. Completed questionnaires were checked for its consistency and completeness daily.

\section{Data management and analysis procedure}

The data entry and cleaning performed using EPI Info version 3.5.1 Statistical package and then exported to SPSS version 16.0 for analysis. Frequencies and proportions were computed as descriptive analysis. Initially using bivariate analysis a crude association between the independent and dependent variables was investigated. Then, those variables with $p$-value $\leq 0.25$ were included in multivariable analysis to determine the predictor variables for the outcome variables. Before further analyses were carried out using multivariable analysis at a significance level of p-value $\leq 0.05$, multicollinearity was checked among selected independent variables using the variance inflation factor and none was found. Additionally, Goodness of fit of the final model was checked by Hosmer and Lemeshow and was found fit.

\section{Operational definition \\ Diarrhea}

Is defined as having three or more loose or watery stools in $24 \mathrm{~h}$, as reported by the mother/caretaker of the child in the past 2 weeks before data collection [1].

\section{Index child}

Refers to a child that will be included in the study from a household to have information on the demographic and health characteristics [13].

\section{Proper disposal of wastes/refuse}

This is a way of disposal of refuses that included burning, burying in a pit or storing in a container and disposing of in a designed site, whereas disposing of in open fields considered as un proper disposal method [14].

\section{Improved water source}

Drinking-water sources protected from outside contamination. This includes protected spring, protected dug well and piped water [13].

\section{Results}

Socio-economic and demographic characteristics of study participant

A total of 537 households with children under the age of 5 years were included in this study with a response rate of $98.35 \%$. Out of the total respondents, 504 (93.9\%) interviews were conducted with mothers of children under-5 years of age and the rest with caretakers. From a total, 478 (89\%) of the respondents were from the rural resident. The Mean age of respondents was $27.86( \pm 4.5$ SD) years. Two hundred eighty-nine (53.8\%) respondents did not attend formal education. The majority of respondents 488 (90.9\%) were housewives. The mean family size of the study participants was $4.67 \quad( \pm 1.48$ SD) (Table 1).

\section{Demographic and health characteristics of indexed children}

Of the total children, 301 (56.1\%) were males. Regarding the age group, 259 (48.2\%) were greater than 24 months, followed by age between 12 and 24 months which 
Table 1 Socioeconomic and demographic characteristics of study participants in Dale District, Southern Ethiopia, October 1-25/ 2017

\begin{tabular}{|c|c|c|c|}
\hline Variables & Category & Frequency(n) & Percent (\%) \\
\hline \multirow[t]{2}{*}{ Residence } & Rural & 478 & 89.0 \\
\hline & Urban & 59 & 11.0 \\
\hline \multirow[t]{2}{*}{ Number of household members } & $<5$ & 292 & 54.4 \\
\hline & $\geq 5$ & 245 & 45.6 \\
\hline \multirow[t]{2}{*}{ Number of under-five children } & One & 487 & 90.7 \\
\hline & Above one & 50 & 9.3 \\
\hline \multirow[t]{3}{*}{ Age of the mother/caretaker } & $15-24$ & 113 & 21.0 \\
\hline & $25-34$ & 379 & 70.6 \\
\hline & $\geq 35$ & 45 & 8.4 \\
\hline \multirow[t]{2}{*}{ Marital status of the mother/caretaker } & Married & 523 & 97.4 \\
\hline & Others & 19 & 2.6 \\
\hline \multirow[t]{2}{*}{ Religion of parents } & Protestant & 509 & 94.8 \\
\hline & Others & 28 & 5.2 \\
\hline \multirow[t]{2}{*}{ Educational status of mother/caretaker } & No formal education & 289 & 53.8 \\
\hline & Formal education & 142 & 26.4 \\
\hline \multirow[t]{2}{*}{ Occupation of the mother/caretaker } & Housewife & 488 & 90.9 \\
\hline & Others & 49 & 9. 1 \\
\hline \multirow[t]{3}{*}{ Age of the child's father } & $15-24$ & 12 & 2.2 \\
\hline & $25-34$ & 313 & 58.3 \\
\hline & $\geq 35$ & 212 & 39.5 \\
\hline \multirow[t]{2}{*}{ The educational level of a child father } & No formal education & 249 & 46.4 \\
\hline & Formal education & 99 & 18.4 \\
\hline \multirow[t]{3}{*}{ Occupation of the child father } & Farmer & 381 & 70.9 \\
\hline & Government employer & 47 & 8.8 \\
\hline & Others & 35 & 6.5 \\
\hline \multirow[t]{3}{*}{ Monthly family income in birr } & $<500$ Birr & 200 & 37.2 \\
\hline & 500-1000 Birr & 228 & 42.5 \\
\hline & $>1000$ Birr & 109 & 20.3 \\
\hline
\end{tabular}

accounts for 157 (29.2\%). The mean ages of indexed children were 23.4 ( \pm 13.9 SD) months. Three hundred ninety-three (96.1\%), 423 (94.6\%) and 439 (92.1\%) of the children received the Rotavirus vaccine, the measles virus vaccine, and Vit A Supplementation respectively. Seventy-three $(13.6 \%)$ of the children had experienced diarrhea in the 2 weeks preceding the study (Table 2).

\section{Behavioral characteristics of respondents}

Two hundred ninety-one (54.2\%) mothers/caretakers wash their hands using soap/ash and water after visits of the latrine. Out of a total of 396 (73.7\%), respondents reported that they practice hand washing before food preparation and $422(78.6 \%)$ after latrine visit. From total respondents, 495 (92.2\%) had a separate container for drinking water storage and 483 (89.9\%) had cover for the drinking water container. Eighty-nine (16.6\%) of respondents treat their drinking water at home (Table 3).

\section{Environmental sanitation characteristics of households}

Of total respondents, 275 (51.2\%) had two and above separate rooms in the house. Out of the total respondents, 496 (92.4\%) had a latrine. Two hundred twentynine $(46.2 \%)$ of the households of respondents had a handwashing facility near to the latrine. From total 489 (91.1\%) latrine facilities were privately owned. In 270(54.4\%) respondents of the households, no feces observed around the latrine hole. Two hundred eighty-five (53.1\%) of households disposed of refuse in open field, With regards to their drinking water source 130 (24.2\%) respondents reported that they get from the unprotected water source. Out of a total, 265 (49.3\%) had consumed 20-1 water or less per day (Table 4). 
Table 2 Demographic and health characteristics of indexed children in Dale District, Southern Ethiopia, October 1-25/2017

\begin{tabular}{|c|c|c|c|}
\hline Variables & Category & Frequency(n) & Percent $(\%$ \\
\hline \multirow[t]{2}{*}{ Sex of the indexed child } & Male & 301 & 56.1 \\
\hline & Female & 236 & 43.9 \\
\hline \multirow[t]{4}{*}{ Age of the indexed child in a month } & Below 6 months & 62 & 11.5 \\
\hline & B/w 6-11 months & 59 & 11 \\
\hline & B/w $12-24$ months & 157 & 29.2 \\
\hline & Greater than 24 months & 259 & 48.2 \\
\hline \multirow[t]{4}{*}{ The birth interval of indexed child } & 1st child & 163 & 30.4 \\
\hline & $\leq 2 \mathrm{yrs}$ & 81 & 15.1 \\
\hline & 2 yrs. -4 yrs & 216 & 40.2 \\
\hline & $\geq 4$ years & 77 & 14.3 \\
\hline \multirow[t]{3}{*}{ Current Breast Feeding (BF) status of the indexed child } & Exclusively breastfeed & 71 & 13.2 \\
\hline & Partially breastfeed & 363 & 67.6 \\
\hline & None breastfeed & 103 & 19.2 \\
\hline \multirow[t]{2}{*}{ The child started Supplementary/Complementary feeding } & Yes & 466 & 86.7 \\
\hline & No & 71 & 13.3 \\
\hline \multirow[t]{2}{*}{ Measles Vaccination status $n=447$} & Yes & 423 & 94.6 \\
\hline & No & 24 & 5.4 \\
\hline \multirow[t]{2}{*}{ Vit.A Supplementation } & Yes & 439 & 92.1 \\
\hline & No & 38 & 7.9 \\
\hline \multirow[t]{2}{*}{ Rota virus immunization } & yes & 393 & 96.1 \\
\hline & No & 16 & 3.9 \\
\hline \multirow[t]{2}{*}{ Nutritional Status } & Under nutrition & 122 & 22.7 \\
\hline & Normal & 415 & 77.3 \\
\hline \multirow[t]{2}{*}{ Presence of diarrhea in the last 2 weeks } & No & 464 & 86.4 \\
\hline & Yes & 73 & 13.6 \\
\hline \multirow[t]{2}{*}{ The child was ever taken to Health institutions, $n=73$} & Yes & 17 & 23.3 \\
\hline & No & 56 & 76.7 \\
\hline \multirow[t]{2}{*}{ Use of ORS to treat child, $n=73$} & Yes & 35 & 47.9 \\
\hline & No & 38 & 52.1 \\
\hline
\end{tabular}

\section{Prevalence of diarrhea}

Seventy three $(13.6 \%)$, 95\% CI $(10.7,16.5 \%)$ of the children had experienced diarrhea in the 2 weeks preceding the study. Out of 73 children who had got diarrhea only $17(23 \%)$ of them taken to a health institution. The study also showed that 38 (48\%) of children with diarrhea received oral rehydration (ORS).

\section{Factors associated with childhood diarrheal disease}

Variables in the bivariate analysis of socio-economic, environmental sanitation conditions, behavioral conditions and child characteristics with respect to childhood diarrhea; which were found at $p$-value $\leq 0.25$ were further considered for multiple logistic regression analysis. Accordingly, mothers'/caregivers' educational status, age of the child, nutritional status of child, hand washing practice of mother/caregiver after latrine visit, mothers/ caregiver handwashing method, methods of refuse disposal and housing floor material were a candidate for multiple logistic regression (Table 5).

Children whose mother/caretakers with no formal education had 3.97 times [AOR: 3.97, 95\% CI (1.60, 8.91)], higher odds of developing diarrhea when compared to those mothers/caretakers with formal education. Children within the age group of 12-24 months had more than 12 times [AOR: 12.18, 95\% CI (1.78, 83.30)] higher odds of developing diarrhea than those aged below 6 months. Under-nourished children had 6.41 times [AOR, 6.41, 95\% CI $(2.47,16.77)$ ] higher odds of developing diarrhea when compared to those with normal. Children of mothers/caretakers who had no habit of washing their hand after latrine visit had 2.73 times [AOR: 2.73, 95\% CI: $(1.05,6.56)]$ higher odds of developing diarrhea when their hands with soap. 
Table 3 Selected behavioral characteristics of respondents in Dale district, Southern Ethiopia, October 1-25/2017

\begin{tabular}{|c|c|c|c|}
\hline Variables & Category & Frequency(n) & Percent(\%) \\
\hline \multirow[t]{3}{*}{ Food child mostly receive } & Cow's milk & 140 & 26.0 \\
\hline & Gruel & 110 & 20.5 \\
\hline & Adults' food & 216 & 40.2 \\
\hline \multirow[t]{2}{*}{ Separately preparation of child food } & Yes & 306 & 57.0 \\
\hline & No & 160 & 29.8 \\
\hline \multirow[t]{3}{*}{ Materials used to feed a child } & Hand & 287 & 53.4 \\
\hline & Bottle & 54 & 10.1 \\
\hline & Spoon & 196 & 36.5 \\
\hline \multirow[t]{2}{*}{ Cover for drinking water storage container } & Yes & 483 & 89.9 \\
\hline & No & 54 & 10.1 \\
\hline \multirow[t]{2}{*}{ Separated container for drinking water } & Yes & 495 & 92.2 \\
\hline & No & 42 & 7.8 \\
\hline \multirow[t]{2}{*}{ Use latrine all the time } & Yes & 489 & 91.1 \\
\hline & No & 48 & 8.9 \\
\hline \multirow[t]{3}{*}{ Methods of washing hands } & Water only & 131 & 24.4 \\
\hline & Water and soap/ash & 291 & 54.2 \\
\hline & Not washing hand & 115 & 21.4 \\
\hline \multirow[t]{2}{*}{ Hand washing after feeding the child } & Yes & 459 & 85.5 \\
\hline & No & 78 & 14.5 \\
\hline \multirow[t]{2}{*}{ Hand washing before feeding the child } & Yes & 396 & 73.7 \\
\hline & No & 141 & 26.3 \\
\hline \multirow[t]{2}{*}{ Hand washing after visiting the latrine } & Yes & 422 & 78.6 \\
\hline & No & 115 & 21.4 \\
\hline \multirow[t]{2}{*}{ Hand washing after cleaning a child's bottom } & Yes & 338 & 62.9 \\
\hline & No & 199 & 37.1 \\
\hline \multirow[t]{2}{*}{ Home treatment of drinking water } & Yes & 89 & 16.6 \\
\hline & No & 448 & 83.4 \\
\hline \multirow[t]{3}{*}{ Age of child started supplementary food } & Less than 6 month & 131 & 24.4 \\
\hline & At 6 month & 259 & 48.2 \\
\hline & Greater than 6 month & 147 & 27.4 \\
\hline \multirow[t]{2}{*}{ Time of initiation of BF during birth } & Within $1 \mathrm{~h}$ & 507 & 94.4 \\
\hline & After $1 \mathrm{~h}$ & 30 & 5.6 \\
\hline
\end{tabular}

Children of mothers/caretakers who had no habit of washing their hands with soap after latrine visit had 3.1 times [AOR, 3.10, 95\% CI, (1.10, 8.67)] higher odds of developing diarrhea when compared with children whose mothers/ caretakers washed their hands.

Children whose family disposes of refuse improper way had above 3 times [AOR, 3.23, 95\% CI, (1.37, 7.60)] higher odds of developing diarrhea than those families properly dispose of refusal. Children whose house had a dwelling with the Mud floor had 3.22 times [AOR: 3.22, 95\% CI $(1.16,8.91)]$ higher odds of developing diarrhea when compared to those households had a dwelling with cement (Table 5).

\section{Discussion}

In this study, the 2 weeks' prevalence of diarrhea among under-five children is in line with the EDHS 2016 national and regional report [8]. But it is lower than other several similar studies conducted in Ethiopia: Eastern Ethiopia (22.5\%) [14], Arbaminch rural community (31\%) [13], Enderta district, Northern Ethiopia (35.6\%) [15] and Enemy district (18.6\%) [16]. similarly, this report is lower than the reports of studies conducted in Northwestern Burundi (32.6\%) [17], West Banga, India (22.36\%) [18] And in Kushtia, Bangladesh (44.5\%) [19]. The lower prevalence report of our study may be due to improved sanitation and hygiene practices of the 
Table 4 Environmental sanitation characteristics of households, in Dale district, Southern Ethiopia, October 1-25/2017

\begin{tabular}{|c|c|c|c|}
\hline Variables & Category & Frequency(n) & Percent (\%) \\
\hline \multirow[t]{2}{*}{ Floor of Housing } & Mud & 389 & 72.4 \\
\hline & Cement & 148 & 27.6 \\
\hline \multirow[t]{2}{*}{ Roof of Housing } & Wood/ thatched & 410 & 76.4 \\
\hline & Corrugated iron & 127 & 23.6 \\
\hline \multirow[t]{2}{*}{ Numbers of rooms } & $<2$ Rooms & 262 & 48.8 \\
\hline & $\geq 2$ Rooms & 275 & 51.2 \\
\hline \multirow[t]{2}{*}{ Latrine availability } & Yes & 496 & 92.4 \\
\hline & No & 41 & 7.6 \\
\hline \multirow[t]{2}{*}{ Ownership of the latrine $n=496$} & Privately & 489 & 91.1 \\
\hline & Shared & 7 & 1.3 \\
\hline \multirow[t]{2}{*}{ Types of toilet facility $n=496$} & amproved & 290 & 58.5 \\
\hline & bunimproved & 206 & 41.5 \\
\hline \multirow[t]{2}{*}{ Availability of handwashing facility near to toilet $n=496$} & Yes & 229 & 46.2 \\
\hline & No & 267 & 53.8 \\
\hline \multirow[t]{2}{*}{ Presence of feces in the latrine hole $n=496$} & Yes & 226 & 45.6 \\
\hline & No & 270 & 54.4 \\
\hline \multirow[t]{2}{*}{ Presence of feces inside the compound } & Yes & 53 & 9.9 \\
\hline & No & 484 & 90.1 \\
\hline \multirow[t]{4}{*}{ Refuse disposal methods } & In-pit & 152 & 28.3 \\
\hline & Open field & 285 & 53.1 \\
\hline & Garbage bin & 11 & 2.0 \\
\hline & Burning & 89 & 16.6 \\
\hline \multirow[t]{3}{*}{ Source of drinking water } & Protected spring/well water & 253 & 47.1 \\
\hline & Unprotected spring/well water & 130 & 24.2 \\
\hline & Pipe & 154 & 28.7 \\
\hline \multirow[t]{2}{*}{ Time to reach a water source } & $\leq 30$ Minutes & 461 & 85.8 \\
\hline & $>30$ Minutes & 76 & 14.2 \\
\hline \multirow[t]{2}{*}{ Water consumption per day } & $\leq 20$ lit & 265 & 49.3 \\
\hline & $>20$ lit & 272 & 50.7 \\
\hline \multirow[t]{2}{*}{ Houses shared with domestic animals } & Yes & 244 & 45.4 \\
\hline & No & 293 & 54.6 \\
\hline
\end{tabular}

indicate types of toilet improved when the toilet is Pit latrine with slab

${ }^{b}$ indicate types of toilet unimproved when the toilet is Pit latrine without a slab or pour-flush latrine

respondents. On the other hand, this study reports a higher prevalence than studies conducted in the Gambia, $7.7 \%$ [20] and in India, (5\%) [21].

This study reports odds of developing diarrheal diseases among children under the age of 5 years were 3.97 times higher among children of mothers/caretakers who had not attended formal education compared with the odds of diarrheal diseases among children whose mothers had attended formal education. This is in line with other studies finding conducted in Arbamich district, Southern Ethiopia [13], Benishangul Gumuz region [11] and Sheko District, South West Ethiopia [22]. Similarily findings from India also showed a relatively higher prevalence of diarrhea among children whose mothers had no education [23]. This might be an educated mother's will have a positive influence on hygienic practice, child feeding, weaning.

The odds of developing diarrheal diseases among children under the age of 5 years were 12 times higher among children aged from 12 to 24 months compared with the odds of diarrheal diseases among children aged below 6 months. This finding is in agreement with other studies conducted in a different part of Ethiopia [13, 14, 22, 24]. Similarly, studies in Bangladesh and India had also shown higher odds of diarrhea in children aged from 12 to 23 months [18]. This might be due to the 
Table 5 Factors Associated with diarrheal disease among under-five children in Dale District, Southern Ethiopia, October 1-25/2017

\begin{tabular}{|c|c|c|c|}
\hline Variables & Category & COR(95\% C.I) & AOR(95\% C.I) \\
\hline \multirow[t]{2}{*}{ The educational level of child-mother/caretaker } & No formal education & $2.7(1.6-4.8)$ & $3.97(1.60,8.81)^{* *}$ \\
\hline & Formal education & 1 & 1 \\
\hline \multirow[t]{4}{*}{ Age of the index child in a month } & Below 6 months & 1 & 1 \\
\hline & B/w 6-11 months & $0.29(0.09-0.93)$ & $2.42(0.25,24.03)$ \\
\hline & B/w 12-24 months & $2.5(1.26-4.8)$ & $12(1.78,83.18)^{* *}$ \\
\hline & Greater than 24 months & $1.4(0.67-2.9)$ & $2.74(0.39,19.09)$ \\
\hline \multirow[t]{2}{*}{ Nutritional status } & Under nourished & $4.91(2.9-8.23)$ & $6.41(2.47,16.77)^{* *}$ \\
\hline & Normal & 1 & 1 \\
\hline \multirow[t]{3}{*}{ Hand washing practice } & Not washing hand & $5.1(2.475-10.7)$ & $3.10(1.10,8.67)^{*}$ \\
\hline & Water only & $6.8(3.427-13.6)$ & $6.41(2.51,16.39)^{* *}$ \\
\hline & Water and soap/ash & 1 & 1 \\
\hline \multirow[t]{2}{*}{ Washing hand before feeding a child } & Yes & $2.21(1.329-3.7)$ & $1.20(0.51,2.81)$ \\
\hline & No & 1 & 1 \\
\hline \multirow[t]{2}{*}{ Washing hand after visiting the latrine } & Yes & $5.45(3.24-9.18)$ & $2.73(1.05,6.56)^{*}$ \\
\hline & No & 1 & 1 \\
\hline \multirow[t]{2}{*}{ Washing hand after cleaning the child's bottom } & Yes & $4.60(2.70-7.81)$ & $1.88(0.78,4.73)$ \\
\hline & No & 1 & 1 \\
\hline \multirow[t]{2}{*}{ A separate container for drinking water storage } & Yes & 1 & 1 \\
\hline & No & $5.33(2.71-0.48)$ & $2.67(0.81,8.75)$ \\
\hline \multirow[t]{2}{*}{ Consumption of water per day } & $\leq 20$ Liters & $2.7(1.60-4.61)$ & $1.27(0.46,3.47)$ \\
\hline & Above 20 Litres & 1 & 1 \\
\hline \multirow[t]{2}{*}{ Housing floor material } & Mud & $2.66(1.33-5.35)$ & $3.22(1.16,8.91)^{*}$ \\
\hline & Cement & 1 & 1 \\
\hline \multirow[t]{2}{*}{ Source of drinking water } & Safe & 1 & 1 \\
\hline & Unsafe & $1.54(1.12-1.99)$ & $2.14(0.96,4.85)$ \\
\hline \multirow[t]{2}{*}{ Refuse disposal methods } & Proper way & 1 & 1 \\
\hline & Improper way & $2.65(1.53-4.57)$ & $3.23(1.37,7.60)^{* *}$ \\
\hline
\end{tabular}

COR crude odds ratio and $A O R$ adjusted odds ratio

${ }^{*} P \leq 0.05,{ }^{*} P \leq 0.01$ was considered statistically significant

combined effects of declining levels of antibodies acquired from the mother, lack of active immunity in the infant, the introduction of food that may be contaminated with fecal bacteria, and direct contact with human or animal feces [25]. In addition to this, at 12 to 23 months infants are either crawling or walking and as such, can easily pick dirt or other contaminated objects $[11,26]$.

Similarly, developing diarrheal diseases is 6.41 times higher among undernourished children compared with normal children. This is in line with a study conducted in Ethiopia, India, and Indonesia [9, 21, 27, 28]. This might be due to malnutrition weakened the immune system leads to an increased susceptibility to diarrheal diseases and other infections [21, 23].

Furthermore, having diarrheal diseases among children under the age of 5 years was 2.73 times higher among children of whose mothers/caretakers not practiced hand washing using soap/ash after toilet visit compared with the odds of diarrheal diseases among children whose mothers/caretakers practice hand washing using soap/ash after latrine visit. This finding is in agreement with studies conducted in Shekko and Dejen district in Ethiopia [22, 29]. In agreement with this study, another study also reported as handwashing with soap particularly before eating, preparing food and feeding children and after using the toilet can considerably reduce the risk of diarrhoea [30]. Handwashing with water and soap is the most effective health intervention for reducing the incidence of diarrhea in children under the age of five [25]. This is can be explained by Soap breaks down grease and dirt that carry germs and disease-causing pathogens [30].

According to the results of this study, the odds of having diarrheal diseases among children under the age of 5 years were 3.23 times higher among children from 
households that disposes of refuse improperly compared with the odds of diarrheal diseases among children from households which properly disposes of refuse. This is in agreement with studies conducted in Ethiopia Enemy District [30], Shekko district [22] and Eastern Ethiopia [14]. This could be due to refuse may contain different pathogens which can cause diarrheal diseases and creates a suitable site for insects breeding. So, improper refuse disposal increases the chance of contact of insect vectors from refuse to food items worsening sanitation and hygiene of family.

The odds of developing diarrheal diseases among children under the age of 5 years were 3.22 times higher among children from households who had a dwelling with the Mud floor compared with the odds of diarrheal diseases among children whose household dwelling with cement floor. This could be due to housing floor material that might be related to a clean home environment [31]. In addition to this, a clean home environment is critical for reducing the transmission of pathogens that cause diarrheal diseases. The house floor material may significantly affect the occurrence of childhood diarrhea [7]. For readers as a limitation, there might be reporting bias during face to face interviews which is tried to be minimized by giving pre-data collection training for data collectors. There might also recall bias on vaccination status, but we tried to limit recall bias by checking the card. There may be a difference among respondents about the definition of diarrhea which was considered during the design, and the definition of diarrhea was explained. In addition to the above limitations, cause and effect cannot be ascertained since it is a cross-sectional study.

\section{Conclusion}

The 2 weeks' prevalence of diarrhea among children under the age of 5 years was $13.6 \%$. The independent variables that were found to be associated with diarrheal diseases among children under the age of 5 years were the educational status of mother/caretakers, age of the indexed child, nutritional status of the indexed child, methods of hand washing, refuse disposal methods and housing floor material. These findings have important policy implications for childhood diarrhoeal disease intervention programs. Government sectors and partners working in collaboration to implement an intervention program focusing on the community to practice proper handwashing techniques at all appropriate times, proper refuse disposal. Improving nutrition and better childcare also highly recommended.

\section{Abbreviations}

BF: Breast Feeding; Cl: Confidence Interval; EDHS: Ethiopia Demographic and Health Survey; Epi info: Epidemiological information software; $\mathrm{HH}$ : House Hold; OR: Odd Ratio; ORS: Oral Rehydration Solution; SPSS: Statistical Package for Social Science; UNICEF: United Nations International Children's Emergency Fund; WHO: World Health Organization

\section{Acknowledgments}

We would like to thank Dale district health office for providing us the necessary information for the accomplishment of our research work and Wolaita Sodo University granted the study. We would like also to extend our gratitude to data collectors and supervisors for their hard work patience in obtaining necessary information.

\section{Authors' contributions}

$\mathrm{BM}$ was involved in the conception, design, analysis, interpretation, report and manuscript writing. WP, F. H, and TB were involved in the design, analysis, interpretation, report and manuscript writing. All authors read and approved the final manuscript.

\section{Authors' information}

BM is Prevention officer, Hamlin Fistula Ethiopia; FH is lecturer, School of Public Health, College of Medicine and Health Sciences, Hawassa University, Hawassa, Ethiopia; WP and TB are lecturers, School of Public Health, College of Health Sciences and Medicine, Wolaita Sodo University, Wolaita Sodo, Ethiopia.

\section{Funding}

This study was funded by Wolaita Sodo University. The funder had no role in the conception, study design, data collection, analysis, writing manuscript and decision to publish.

\section{Availability of data and materials}

The datasets used and/or analyzed during this study are available from the corresponding author and provided on a reasonable request.

\section{Ethics approval and consent to participate}

Ethical approval and clearance were obtained from Wolaita Sodo University Ethical Review Committee. An official letter of cooperation was obtained from the regional health bureau to the Dale district health office. After telling the purpose and procedures of the study, all respondents' were asked for their willingness and informed written consents were obtained. For those not willing to take part in the study, their right was respected to withdraw from the study. All responses were kept confidential and children with diarrhea during the visit were advised to seek treatment. The study did not adversely affect the rights and welfare of the subjects and no financial compensation or provision was made.

\section{Consent for publication}

Not applicable.

\section{Competing interests}

The authors declare that they have no competing interests.

\section{Author details}

${ }^{1}$ Hamlin Fistula Center Yirgalem, Yirgalem, Ethiopia. ${ }^{2}$ School of Public Health, College of Health Sciences and Medicine, Wolaita Sodo University, Wolaita Sodo, Ethiopia. ${ }^{3}$ School of Public Health, College of Health Sciences and Medicine, Hawassa University, Hawassa, Ethiopia.

Received: 2 April 2019 Accepted: 30 August 2019

Published online: 06 September 2019

\section{References}

1. UNICEF/WHO. Why children are still dying and what can be done?. 2009.

2. WHO. Diarrhoeal disease Fact sheet. 2015.

3. Centers for Disease Control and Prevention; Department of Health and Human Services for disease control and prevention in the United State; 2013. Diarrhea: Common IIIness, Global Killer. https:/www.cdc.gov/healthywater/pdf/global/ programs/Globaldiarrhea508c.pdf. Accessed Oct 2017.

4. International Vaccine Access Center (IVAC): Pneumonia and diarrhea Progress report: Johns Hopkins Bloomberg School of Public Health; 2014. https://www.jhsph.edu/ivac/wp-content/uploads/2018/04/IVAC-2014Pneumonia-Diarrhea-Progress-Report.pdf. Accessed Sept 2017. 
5. UNICEF. Committing to child survival: a promise renewed, Progress report. 2013.

6. WHO/UNICEF. Levels \& Trends in child mortality report. 2011.

7. UNICEF. Pneumonia and diarrhea tackling the deadliest diseases for the world's poorest children. 2012.

8. Central Statistics Authority \& ORC Marco. Ethiopia Demographic and Health Survey. Calverton: ORC Macro in Addis Ababa; 2016.

9. Alemu T, Mezgebu Y, Akilew A. Prevalence and determinants of childhood diarrhea among graduated households, in the rural area of Shebedino district, Southern Ethiopia, 2013. Science. 2014;2(2):243-51.

10. Dale District Health Office. Annual report. 2015

11. Mihrete TS, Alemie GA, Teferra AS. Determinants of childhood diarrhea among underfive children in Benishangul Gumuz regional state, north West Ethiopia. BMC Pediatr. 2014;14(1):102.

12. $\mathrm{WHO}$, Multicentre Growth Reference Study Group. Reliability of anthropometric measurements in the WHO multicentre growth reference study. Acta Paediatr Suppl. 2006;450:39-47.

13. Mohammed S, Tamiru D. The burden of diarrheal diseases among children under five years of age in Arba Minch District, southern Ethiopia, and associated risk factors: a cross-sectional study. Int Sch Res Notices. 2014; 2014.

14. Mengistie $B$, et al. Prevalence of diarrhea and associated risk factors among children under-five years of age in eastern Ethiopia a cross-sectional study. Open J Prev Med. 2013;3(7):446-53.

15. Berhe HM, et al. Prevalence of diarrhea and associated factors among children under-five years of age in Enderta Woreda, Tigray, northern Ethiopia. Intl J Therapeutic App. 2016;31:32-5.

16. Mamo A, Hailu A. Assessment of prevalence and related factors of diarrheal diseases among under-five Year's children in Debrebirehan referral hospital, Debrebirehan town, north Shoa zone, Amhara region, Ethiopia. Open Access Library J. 2014;1:1-14. http://www.oalib.com/paper/pdf/3000873.

17. Katharina $D$, et al. Diarrhoea prevalence in children under the age of five 530 years of age in rural Burundi, an assessment of social and behavioral factors Q7 531 at the household level. Glob Health Action. 2014.

18. Gupta A, Sarker G, Rout AJ, Mondal T, Pal R. Risk correlates of diarrhea in children under 5 years of age in slums of Bankura, West Bengal. J Global infect Dis. 2015;7(1):23.

19. Afroza Khatun S, et al. A cross-sectional study on the prevalence of diarrhoeal disease and nutritional status among children under 5-years of age in Kushtia, Bangladesh. Sci J Public Health. 2013;1:26-61.

20. Saha D, et al. Health care utilization and attitudes survey understanding diarrheal disease in the rural Gambia. Am J of Trop Med Hyg. 2013; 89(1):13-20

21. Gupta A, et al. Study of the prevalence of diarrhea in children under the age of five years and its association with wasting. Indian J Sci Res. 2014;7(1): 1315-8.

22. Teklemichael G, Mohammed T, Wondwosen K. Assessment of the risk factor of diarrheal disease in under-five children among the health extension model and non-model family in Sheko district rural community, Southwest Ethiopia. BMC Public Health. 2014;14:395.

23. Suri S, Kumar D, Mail ID. Diarrhoeal diseases and its associated factors among children 1-5 years of age in a rural area of Jammu. Health. 2015;3(3).

24. Alambo KA. The prevalence of diarrheal disease in under five children and associated risk factors in Wolitta Soddo Town, Southern, Ethiopia. ABC Res Alert. 2015;3(2).

25. Dessalegn M, Kumie A, Tefera W. Predictors of under-five childhood diarrhea: Mecha District, West Gojam, Ethiopia. J. Health Dev. 2011;25(3): 192-200.

26. Dessalegn M, Kumie A, Tefera W. Predictors of under-five childhood diarrhea, Mecha District, West Gojjam, Ethiopia. Ethiop J Health Dev. 2014;25(3).

27. Asfaw M, Wondaferash M, Taha M, Dube L. Prevalence of undernutrition and associated factors among children aged between six to fifty nine months in Bule Hora district, South Ethiopia. BMC Public health. 2015; 15(1):41.

28. Agustina R, Sari TP, Satroamidjojo S, Bovee-Oudenhoven IM, Feskens EJ, Kok FJ. Association of food-hygiene practices and diarrhea prevalence among Indonesian young children from low socioeconomic urban areas. BMC Public Health. 2013;13(1):977.

29. Mossie TB. Demeke Getu Tadesse, Addisu Workineh Kassa. Childhood diarrheal disease among children under the age of five years at Dejen district, Northwest Ethiopia. Am J Health Res. 2014;2(4):177-81.
30. Ayele A, Awoke W, Tarekegn M. Crossectional survey; assessment of diarrheal disease prevalence and the associated factors among children under five in Enemay district, northwest Ethiopia. Global J Med Res. 2014.

31. UNICEF. Committing to child survival: a promise renewed Progress report. 2012

\section{Publisher's Note}

Springer Nature remains neutral with regard to jurisdictional claims in published maps and institutional affiliations.
Ready to submit your research? Choose BMC and benefit from:

- fast, convenient online submission

- thorough peer review by experienced researchers in your field

- rapid publication on acceptance

- support for research data, including large and complex data types

- gold Open Access which fosters wider collaboration and increased citations

- maximum visibility for your research: over $100 \mathrm{M}$ website views per year

At $\mathrm{BMC}$, research is always in progress.

Learn more biomedcentral.com/submissions 